\title{
Millionmannen
}

\author{
Han har fått kong Olav Vs kreftforskningspris, har bidratt til nobels fredspris og har mottatt \\ titalls millioner i forskningsstipender. Men epidemiolog og kreftforsker Eiliv Lund synes selv
} at han er litt lat.

- Jeg har aldri jobbet veldig mye eller vært spesielt sliten. Ja, jeg er kanskje litt lat, sier Eiliv Lund og tar en slurk av den ferske caffèlatten.

Klokken er litt over ni en kald høstmorgen i nord. Den anerkjente epidemiologen har startet dagen akkurat som han pleier litt senere enn kollegene, med en forskningsartikkel i venstre hånd og en kaffe fra farmasikantinen i høyre.

Men lat - skal vi tro på det?

Lund er en av Universitetet i Tromsøs mest prisbelønte forskere. Han er forskningsleder for den verdenskjente NOWACstudien (kvinner og kreft) og mottager av intet mindre enn to toppstipender fra det europeiske forskningsrådet.

Ingen andre i landet har klart det.

- Får man til det hvis man er lat?

- Jeg liker å jobbe i et rolig og konsentrert tempo, og starter alltid dagen her i kantinen, litt unna alle de andre. Jeg leser og funderer på hva jeg skal gjøre resten av dagen. Så går jeg innom noen av kollegene på prosjektet vårt og hører hva som skjer den dagen. Management by walking, som det heter.

Han hater fulle kalenderbøker, plingende e-postvarsler og videokonferanser. Han setter seg helst på flyet umiddelbart hvis han må prate med noen som er utenbys og tenker aller best når han går tur.

Kona mener han har en pedaldrevet hjerne.

- For en forsker er det viktigste å vite hvordan hjernen fungerer best, og det er jeg etter hvert blitt ganske god på. Jeg har aldri jobbet meg i hjel eller hatt masse bistillinger, sier Lund og heller i seg det siste av kaffeskummet.

\section{Hyppige jobbskifter}

Men veien til å bli en av universitetets fremste forskere har vært kronglete. Lund, som alltid har vært god med tall, prøvde seg først som student $i$ teknisk fysikk ved Norges tekniske høgskole, men ble raskt forbigått av «sære, begavede tallknusere».

Valget falt på medisinen, og etter turnustjeneste i Fredrikstad og Mo i Rana tenkte nyutdannede Lund at han skulle prøve seg som kliniker i allmennpraksis i Bergen.

- Det tok tre måneder, så begynte jeg å kjede meg, forklarer han og myser. - Det var mange enkle plager, og oppi det skulle man identifisere tegn på alvorlig sykdom. Det var vanskelig for meg, sier han.

Lund vendte derfor tilbake til sin interesse for psykiatri fra studietiden og fikk jobb ved Sandviken psykiatriske sykehus. - På den tiden var det et merkelig sted. Jeg husker de flagget da pasientene hadde vært der i 50 år, sier han og rister på hodet. - Det var heldigvis slutten på den tunge psykiatribehandlingen i Norge, og mye ble forandret senere.

Da han etter hvert traff kollega og samfunnsmedisiner Tor Bjerkedal ble det åpenbart at han trivdes bedre med tall. - Vi hadde

\section{«Vektleggingen av at vi skal være verdens- ledende på forskning er farlig»}

en perfekt akademisk match. Det var min inngang til epidemiologien.

Etter noen år i Kreftregisteret og Helsedirektoratet søkte han et professorstipend i epidemiologi i Tromsø og flyttet nordover. Tidligere kolleger og kullinger hadde anbefalt ham det relativt nye universitetet, som skulle ha flust av muligheter for unge forskere.

Selv mener han at han også var arvelig disponert for å bli betatt av Nord-Norge. - Faren min var epidemilege i Nord-Norge under krigen og fortalte historier fra den tiden. Kanskje lå det $\mathrm{i}$ underbevisstheten da jeg tok valget om å flytte nordover.

I Tromsø fortsatte Lund arbeidet med et forskningsprosjekt om kvinner, p-piller og kreftrisiko, et prosjekt som skulle vise seg å forme resten av hans forskerkarriere.

- Nede i Oslo og i Kreftregisteret hadde vi jobbet med en pasient-kontroll-studie om p-piller og brystkreft hos unge kvinner. Vi hadde publisert at p-piller økte risikoen for kreft $\mathrm{og}$ hadde fått en del oppmerksomhet på grunn av dette. Men problemet med denne forskningsmetoden var jo at vi snakket med to grupper, de syke og de friske, og disse gruppene kan oppfatte spørsmålene forskjellig. Vi bestemte oss derfor for å lage en prospektiv studie - altså å følge kvinner jevnlig $\mathrm{i}$ årene fremover og etter hvert se hvem som ble syke.

Da finansieringen var på plass $i$ begynnelsen av 1990-årene, sendte Lund og kollegene ut 100000 brev med spørreskjema om p-pillebruk og helse. Starten på Kvinner og kreft-studien var et faktum. De neste årene samlet de jevnlig inn blod- og vevsprøver fra tusenvis av kvinner i Norge.

\section{Måtte starte på nytt etter ti år}

Ved millenniumsskiftet og kartleggingen av menneskets DNA satt Eiliv Lund og funderte i Lyon.

- Alle snakket om at denne kartleggingen var et paradigmeskifte og at man nå ville kunne se på arvelig disposisjon for kreft. Jeg var ikke så veldig opptatt av akkurat det, for vi epidemiologer vet jo at kreftrisikoen hovedsakelig er påvirket av livsstilen. Det er ikke bare arv. Flytter du en gruppe mennesker fra Japan til Hawaii, får de den samme kreftforekomsten som de på Hawaii i løpet av en generasjon eller to. Miljøet påvirker risikoen.

For å følge utviklingen i kreftrisiko måtte Lund ha tak i kopiversjonen av genene våre, mRNA, som ikke hadde vært samlet inn i de første blodprøvene. Forskerteamet måtte begynne på nytt med innsamling av blodprøver ti år etter at de hadde begynt.

- Jeg er aldri blitt stresset av store omveltninger i forskningsprosjekter og tar utfordringene som de kommer. Vi skjønte at dette var noe vi måtte gjøre, og at resultatet ville bli en enorm biobank med verdifull informasjon om genenes funksjon hos disse kvinnene, sier han.

I dag har prosjektet 172000 kvinnelige norske deltagere og en biobank med over 50000 spesielle blodprøver og nedfryst vev. Målet er at man i fremtiden skal kunne bruke en blodprøve som diagnostisk test på brystkreft og kanskje kunne avsløre forstadier til kreft.

- Kan vi kaste mammografiapparatet?

- Vi er langt unna det nå, men i fremtiden er det ikke utenkelig. 


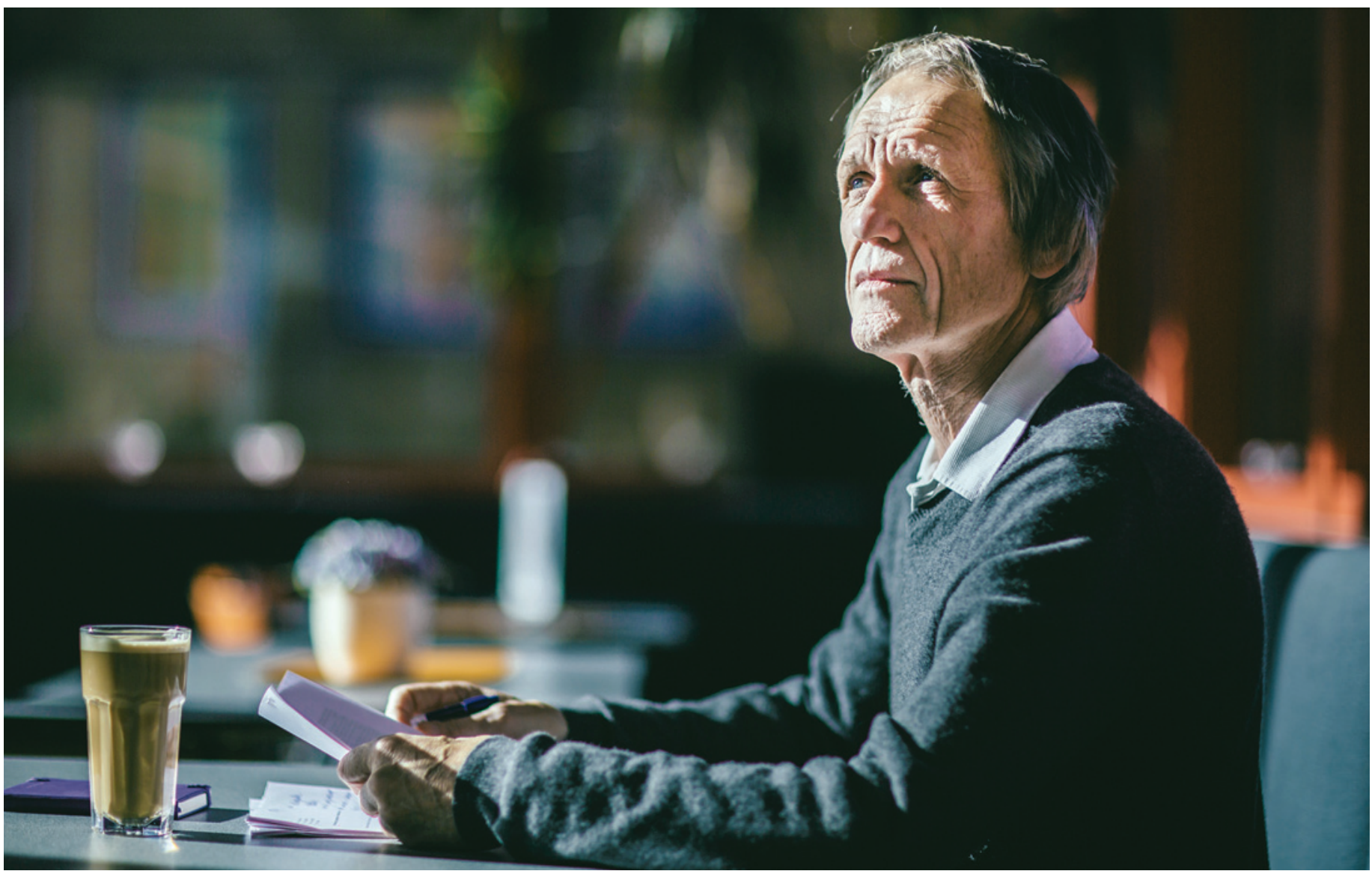

Eiliv Lund starter dagen rolig med kaffe og artikkellesing i kantinen. Foto: Marius Fiskum

\section{Eiliv Lund}

Født i 1947 i Bergen

- Cand.med. fra Universitetet i Oslo, 1974

- Turnuslege, Fredrikstad sentralsykehus 1974- 75

- Distriktsturnustjeneste, Mo i Rana 1975

- Assistentlege, Sandviken psykiatriske sykehus 1975-78

- Reservelege, Kreftregisteret 1979-84

- Leder for Kontor for klinisk forskning. Radiumhospitalet 1985-88

- Spesiallege, Helsedirektoratet 1990

- Førsteamanuensis og professor ved Universitetet i Troms $\varnothing$ - Norges Arktiske Universitet fra 1990

- Prosjektleder for Kvinner og Kreft-studien fra 1991

- Kong Olav Vs kreftforskningspris 2002

- Advanced Investigators Grant, det europeiske forskningsrådet 2008

- Proof Of Concept-tildeling, det europeiske forskningsrådet 2015

\section{Nytenkende forskning}

Det europeiske forskningsrådet (ERC) har stemplet prosjektet som «usedvanlig ambisiøst, nytenkende og ukonvensjonelt», og daværende universitetsrektor Jarle Aarbakke omtalte den første stipendtildelingen som «like stort som at Tromsø Idrettslag skulle slå Manchester United 3-0 på bortebane».

Lund har aldri vært spesielt opptatt av fotball, men setter pris på ros.

- Universitetet verdsetter slike utmerkelser og stipender. Ministere og forskere snakker om det når de kommer hit. Nå er vi i forskningsgruppen kommet et godt stykke på vei, men fortsatt gjenstår det mye. Å erstatte mammografiapparatet med en blodprøve vil være spesielt nyttig i fattige land, men det er for tidlig å si hvordan dette vil utvikle seg, sier han.

- Du har fått flere titalls millioner kroner til forskningen din. Hvordan er det å disponere så mye penger?

- Det har gått helt fint på grunn av en fantastisk økonomisjef med en sterk sans for tall. Jeg synes vi har forvaltet midlene godt, og alt har gått gjennom revisjonen uten problemer. Mest har gått til driftsmidler, forklarer han, og legger til: - Dette instituttet har hatt som filosofi ikke å ha eget laboratorium, så vi har kjøpt tjenester. Noen er ganske dyre, og det er en svakhet. Staten bygger infrastruktur, men gir ikke universitetene frie driftsmidler av betydning. Kanskje er det for mange forskere i forhold til driftsmidler og teknisk hjelp, og det kan på sikt føre til ineffektive forskere. Reiser man til utlandet, ser man tydelig forskjell, forteller han.

Lund ønsker ikke så mye oppmerksomhet omkring sine egne priser og stipender, men vrir praten over på hva et stipend prinsipielt betyr.

\section{Viktig å støtte de små}

- Proof of Concept-stipendet fra det europeiske forskningsrådet og flere av de stipendene vi har fått, er uttrykk for ønsket om å stimulere til nytenkning hos forskere. Det har jeg sans for. I mange år har de store sentrene for fremragende forskning mottatt en stor del av støtten.

Han gestikulerer med hendene: - Vi har fått stipender uten for strenge retningslinjer, og det har vært gull verdt. Det er ideen som teller og at den som får pengene kan gjennomføre den. Ingen betingelse om hvor dette skal skje, ingen påtvungne samarbeidspartnere, ingenting av det vi i Norge legger så mye vekt på. 
Professoren er klar på at dette er veien å gå for Forsknings-Norge $\mathrm{i}$ årene fremover. - Jeg tror dette med å støtte de største er i ferd med å bli et problem her i landet. Forskningsrådet vil helst ha store søknader, men hvis vi bare gir penger til sentrene for fremragende forskning, har vi ikke mulighet til å støtte den lille, engasjerte forskeren når han eller hun kommer med den geniale ideen $\sin$.

- Har du selv vært den lille, engasjerte forskeren du prater om?

- På en måte, ja. Vi har jo holdt på med ting andre har ment at har vært umulig. Og etter 15 år begynner vi å bevise at ideene våre kanskje ikke var så dumme. De første årene publiserte vi veldig få artikler, men nå kommer det seg.

- Hvordan synes du det står til med forskningen i Norge i dag?

- Jeg synes først og fremst vi må være obs på hvor små vi er og hva vi bør forvente. Fordelen med å være epidemiolog er at du kan telle. Vi er fem millioner mennesker i Norge i dag, og norske forskere er like intelligente som forskere i utlandet. Men vi er fortsatt bare like mange som befolkningen i de vestlige bydelene i Paris. Vektleggingen av at vi skal være verdensledende på forskning er farlig.

- Hvorfor?

- Det er som mediene før hvert OL: De hausser opp forventningene, så oppnår vi ikke de ventede resultatene og blir skuffet. Nylig skulle jeg vurdere en artikkel fra universitetet i Shandong, et sted jeg ikke ante hvor var. Et kjapt søk på nettet viste at det er en region i Kina med over 100 millioner innbyggere. Vi må ikke miste perspektivet, forklarer Lund.

\section{Fotografisk hukommelse}

Han snakker stadig om ideer. Kolleger beskriver ham som ultrakreativ.

I studietiden lærte han artikkelskriving som redaktør i studenttidsskriftet Asculap, og han var med i oppstarten av den norske avdelingen av Leger mot atomvåpen, som vant fredsprisen i 1985.

Nå vil han at forskerne hans skal lære engasjement og kreativitet gjennom kurs ved inngangen til forskerkarrieren.
- Og der er det viktigste selvinnsikt, som jeg nevnte tidligere. Man må vite hvor og hvordan man er mest kreativ og produktiv. Her inne, for eksempel, får jeg ingen nye ideer, sier han, og peker rundt på det ryddige, litt mørke kontoret. På veggen henger et par diplomer, og i hyllen står en skulptur han kjøpte for noen prispenger.

Intervjuet måtte flyttes hit underveis fordi farmasikantinen ble for bråkete. Lund er sensitiv for slikt.

- Jeg er var for forstyrrende elementer og ganske visuelt sensitiv. Det er grunnen til at jeg ser lite på TV og nesten aldri er på kino.

\section{«Hvis vi bare gir penger} til sentrene for fremragende forskning, har vi ikke mulighet til

å støtte den lille, engasjerte forskeren når han eller hun kommer med den geniale ideen sin»

Bilder av vold, for eksempel, fester seg veldig tydelig. Jeg har en visuell hukommelse som er nyttig i forskningssammenheng, jeg husker tabeller og hele A4-sider utenat, men privat kan det være en ulempe, sier han.

Blir det for mange distraksjoner og han vil tenke klart, tar han seg en spasertur.

- Jeg får flest ideer når jeg går tur, enten på hytta i Lyngen eller helst gatelangs i Paris eller Lyon.

\section{Ble frankofil i studietiden}

Det var under studietiden av kjærligheten til Frankrike og alt fransk kom. En medisinstuderende bror i Strasbourg inspirerte Lund til å ta en pause i studiene og bruke et halvår på haiking i Frankrike.
Han ble betatt av landskapet, maten og folket.

- De månedene viste seg i ettertid å bli viktige. Jeg lærte fransk og har på grunn av det knyttet tette forskningsbånd til franske forskere. Og så kan jeg spise middag hjemme hos dem og snakke språket - det knytter også bånd på en annen måte enn i et møterom, forklarer han.

Han besøker landet flere ganger i året og blir inspirert av forskerne han møter der.

- Vi diskuterer stadig ideer. For eksempel tenker vi på at mye av det vi vet om immunologi i dag, stammer fra museforskning, og at tiden er inne for å sette søkelyset på menneskets celler og immunologi. Mus har jo en helt annen hormonregulering enn oss, og vi er nødt til å reorientere oss. Hva er human kunnskap og hva er kunnskap om mus? Spennende, forklarer han.

\section{Må gi livsstilsråd}

Som høyt rangert kreftforsker blir Lund stadig kontaktet av mediene, som vil ha ham til å kommentere de nyeste kostholdsrådene og livsstilsanbefalingene.

- De spør hvor mye tran vi skal ta, om rødt kjøtt er farlig og om hvor mye vi skal trene. Svaret mitt er kjedelig enkelt.

- Hva svarer du?

- Som de gamle grekere: sofrosyne måtehold, en av de fire kardinaldydene. Man skal følge den gylne middelvei. Spise variert, ikke få for mye eller for lite av noe næringsstoff, og være i aktivitet. Hvis du går inn på et eldresenter i Norge i dag, ser du at de eldste der ofte er små, lette damer som har levd et aktivt liv uten for mye stress. Litt som i de franske landsbyene, smiler Eiliv Lund.

\section{Martin Hotved}

martin@hotvedt.no

Universitetssykehuset Nord-Norge 